\title{
PROFIL KUALITAS LAYANAN JASA PENDIDIKAN TINGGI PERGURUAN TINGGI SWASTA DI JAKARTA
}

\author{
Heni Mularsih ${ }^{1}$ dan Lerbin Aritonang ${ }^{2}$ \\ ${ }^{1}$ Fakultas Psikologi, Universitas Tarumanagara \\ Email: henim@mku.untar.ac.id \\ ${ }^{2}$ Fakultas Ekonomi, Universitas Tarumanagara \\ Email: aritonanglerbin@gmail.com
}

\begin{abstract}
ABSTRAK
Penelitian ini bertujuan mengetahui gambaran kualitas pelayanan pada pendidikan tinggi swata di Jakarta. Penelitian dilakukan pada perguruan tinggi swasta (PTS) yang tergabung pada Kopertis Wilayah III. Instrumen pengumpulan data dengan cara penyebaran kuesioner. Materi kuesioner dikembangkan dari lima dimensi kualitas pelayanan pada SERVQUAL (Service Quality) yang dikembangkan oleh Parasuraman, Zeithaml dan Berry atau disingkat PZB (1985, 1988, 1991, 1994). Validasi instrumen yang digunakan yaitu validitas isi (untuk mencocokkan pernyataan angket dengan 5 dimensi SERQUAL). Sampel dipilih secara Convenience sebanyak 5 PTS di Jakarta Barat. Sampel dalam penelitian ini mahasiswa sebagai pengguna jasa. Validitas instrumen melalui face validity dan content validity dilakukan oleh pakar. Revisi instrumen hasil validasi pakar kemudian diuji validitas dan reliabilitas menggunakan SPSS.Teknik analisis data dengan menggunakan analisis statistik deskriptif dengan SPSS. Hasil penelitian menunjukkan bahwa gambaran pelayanan jasa pendidikan tinggi, baik dari 5 perguruan tinggi yang menjadi sampel, maupun dari lima dimensi pengukuran termasuk dalam kategori "cukup" sehingga pelayanan jasa masih perlu untuk ditingkatkan. Kata kunci; instrumen, kualitas pelayanan, pendidikan tinggi
\end{abstract}

\section{PENDAhUluan}

Persaingan antarperguruan tinggi semakin ketat. Untuk menjaga kelangsungan hidupnya, salah satu upaya yang dilakukan perguruan tinggi adalah meningkatkan kualitas pelayanan. Melalui pelayanan para mahasiswa akan mendapatkan kepuasan. Para mahasiswa yang memeroleh kepuasan melalui pelayanan jasa yang baik dapat berdampak pada peningkatan kemampuan dan kinerjanya (Jain, et.al dalam Susanti, 2015). Oleh karena itu, perguruan tinggi sebagai lembaga pendidikan untuk mempersiapkan sumber daya manusia yang berkualitas, perlu melakukan perbaikan dalam pelayanan jasa. Sebagaimana dalam Undang-Undang Nomor 20 Tahun 2003 tentang Sistem Pendidikan Nasional dan Peraturan Pemerintah Nomor 19 Tahun 2005 tentang Standar Nasional Pendidikan, setiap penyelenggara pendidikan baik internal maupun eksternal wajib menjamin mutu yang salah satunya melalui peningkatan kualitas pelayanan.

Namun, berapa penelitian menunjukkan bahwa kualitas pelayanan di pendidikan tinggi belum dapat memuaskan mahasiswa. Hasil penelitian menunjukkan bahwa dari 20 atribut pelayanan yang dibutuhkan mahasiswa Jurusan Akuntansi XYZ, keseluruhan variabelnya memiliki gap bernilai negatif sehingga peningkatan kualitas pelayanan harus diupayakan untuk diperbaiki oleh pihak Jurusan.Dari hasil penelitiannya, variabel fasilitas/peralatan pendukung (laboratorium, dan sebagainya) menjadi prioritas utama dilakukan perbaikankarena memiliki nilai bobot yang paling besar. Selain itu, masalah pelayanan yang perlu diupayakan terkait dengan prioritas utama, yaitu tingkat kompetensi dosen karena memiliki nilai tingkat kepentingan relatif tertinggi. Penelitian tersebut mengharapka adanya peningkatan kualitas kualitas pelayanan Jurusan Akuntansi XYZ (Bangun, A. Ginting, R, \& Tarigan, U., 2013).

Tingkat kepuasan mahasiswa terhadap kualitas pelayanan masih rendah. Hal ini digambarkan dengan adanya keterbatasan pihak kampus untuk menyediakan dosen bagi mahasiswa yang 
berkebutuhan khusus. Selain itu, masih ada gap performance dengan kinerja rendah untuk setiap fakultas (Siregar \& Zulaihah, 2010)

Kualitas pelayanan jasa di Fakultas Teknik Universitas X belum sepenuhnya memuaskan mahasiswa karena hampir seluruh variabel pelayanan yang dinilai memiliki nilai gap yang negatif. Fasilitas yang diberikan pihak kampus belum sesuai dengan biaya uang kuliah yang dibayarkan oleh mahasiswa sehingga perlu dilakukan perbaikan terhadap fasilitas utama dan penunjang yang dapat dirasakan oleh mahasiswa teknik untuk memperlancar kegiatan belajar dan mengajar (Hasibuan dan Sutrisno, 2017). Berdasarkan beberapa penelitian tentang kualitas jasa yang hasilnya belum memuaskan, peneliti tertarik untuk mengetahui bagaimana profil kualitas pelayanan jasa pendidikan tinggi lain yang berada di area Jakarta Barat.

Untuk memperoleh data tentang gambaran pelayanan jasa pendidikan tinggi diperlukan suatu kuesioner sebagai instrumen yang dikembangkan dari dimensi pelayanan jasa. Kuesioner yang digunakan sebagai instrumen untuk memperoleh data profil pelayanan jasa di pendidikan tinggi dalam penelitian ini yaitu model SERQUAL dengan lima demensi (PZB, 1988) sesuai dengan jumlah dimensi yang juga digunakan oleh beberapa peneliti di lembaga pendidikan (Acosta \& Alexander, 2005; Coutinho, 2007; Tomassini, Aquino \& Carvalho, 2008; Franco \& Furtado, 2010; 2012; Lourenco \& Knop, 2011 dalam Borges, Santos dan Leal, 2014).

Instrumen yang sering digunakan untuk mengukur kualitas pelayanan jasa yaitu SERVQUAL yang dikembangkan oleh Parasuraman, Zeithaml, Berry atau disingkat PZB (1985, 1988, 1991), meskipun model SERQUAL ini terdapat beberapa kelemahan (Babakus dan Boller,1992; Brady dan Cronin,2001; Hussey,1999). Menurut PZB, kualitas pelayanan jasa SERQUAL diwujudkan dalam lima dimensi (1988), tetapi ada peneliti lain yang menemukan tujuh dimensi (Carman, 1990), dua dimensi (Mels, Boshoff, dan Nel, 1997), dan satu dimensi (Cronin dan Taylor, 1992).

Ada beberapa penelitian mengenai instrumen kualitas pelayanan jasa yang sudah dilakukan di berbagai perguruan tinggi dengan menggunakan dimensi yang berbeda-beda (misalnya, Ansary, Jayashree, dan Malarvizhi, 2014; Borges, Santos dan Leal, 2014; Firdaus, 2006; Ford, Joseph, dan Joseph, 1999; Green, 2014; Holdford dan Patkar, 2003; Mahmoud dan Khalifa, 2015; Mukhtar, Anwar, Ahmed dan Baloch, 2015; Nassef, 2014; Sanchez dan Pazos, 2014).

\section{Kualitas Layanan Pendidikan}

Kualitas merupakan suatu hal yang penting dalam suatu usaha baik yang bersifat barang maupun jasa. Dengan kualitas yang tinggi, suatu usaha dapat lebih unggul dari pesaing. Sebagaimana dinyatakan oleh Feigenbaum (1996), kualitas merupakan kekuatan penting yang dapat membuahkan keberhasilan baik di dalam organisasi maupun pertumbuhan lembaga. Hal ini juga dapat diterapkan dalam peningkatan mutu pendidikan. Menurut Gunawan (2012), kemampuan penyedia jasa dalam memenuhi harapan/kepentingan pelanggannya secara konsisten dapat dijadikan ukuran baik tidaknya kualitas layanan.

Mengingat anjuran pemerintah bahwa setiap perguruan tinggi harus memilki standar kualitas layanan, maka penting bagi setiap perguruan tinggi mempunyai standar kualitas yang terukur melalui suatu instrumen. Sejauh ini belum ada keseragaman ukuran yang digunakan pendidikan tinggi atas. Dengan demikian, rumusan masalah dalam penelitian ini, yaitu (1) Bagaimana membuat 
instrumen layanan jasa yang valid berdasarkan dimensi Serqual untuk digunakan di beberapa perguruan tinggi yang tergabung dalam Kopertis Wilayah III di atas?, (2) Bagaimana gambaran kualitas layanan jasa pendidikan tinggi di beberapa perguruan tinggi itu?, dan (3) Bagaimana hasil pemetaan kualitas layanan berdasarkan dimensi Serqual di beberapa perguruan tinggi?

\section{Unsur-Unsur Kualitas Layanan SERQUAL}

Parasuraman (2001) menyatakan bahwa konsep kualitas layanan yang berkaitan dengan kepuasan ditentukan oleh lima unsur, yaitu responsibility, assurance, tangible, emphaty, dan reliability, yang kelima unsur tersebut biasa dikenal dengan istilah'RATER. Kulaitas layanan RATER digunakan sebagai acuan dalam mweujudkan layanan di bidang organisasi kerja untuk memecahkan berbagai kesenjangan (gap) antara pelayanan yang diberikan dalam memenuhi tunututan pelayanan masyarakat. Untuk lebih jelasnya, unsur-unsur RATER akan dijelaskan sebagai berikut.

\section{Bukti Fisik (Tangibles)}

Bukti fisik dalam kualitas layanan adalah bentuk perwujudan secara fisik yang dapat dilihat atau digunakan oleh karyawan yang menunjukkan performan kerjanya dalam membantu pelanggan sehingga mereka merasa puas atas pelayanan yang diterima, (Parasuraman, 2001).

Bentuk layanan fisik biasanya berupa sarana dan prasarana atau fasilitas fisik pelayanan yang disediakan, teknologi yang digunakan, dan performance pemberian layanan yang sesuai dengan karakteristik pelayanan yang diberikan untuk menunjukkan kinerja yang dapat diberikan dalam bentuk pelayanan fisik yang dapat dilihat.

\section{Keandalan (Reliability)}

Yang dimaksud dengan keandalan adalan kemampuan pegawai yang memiliki pengetahuan, keahlian, dan sikap profesionalisme kerja yang tinggi dalam memberikan pelayanan dengan segera, cepat, dan lancar kepada sehingga menghasilkan bentuk pelayanan yang memuaskan, tanpa ada keluhan dan kesan berlebihan atas pelayanan yang telah diberikan (Parasuraman, 2001).

Menurut Sunyoto (2004), bentuk keandalan dalam pelayanan tercermin dalam (1) pemberian pelayanan sesuai dengan tingkat pengetahuan yang dimiliki berdasarkan uraian kerjanya, (2) pemberian pelayanan kepada pelangga sesuai dengan keterampilan kerja secara efektif dan efisien, (3) pelayanan yang diberikan kepada pelanggan sesuai dengan pengalaman kerjanya, sehingga memiliki penguasaan rincian kerja dan dapat melakukan aktivitas pelayanan secara cepat dan lancar, (4) memiliki keandalan dalam penguasaan teknologi sehingga dapat memberikan pelayanan secara tepat sesuai menghasilkan output sesuai dengan teknologi yang dikuasai.

\section{Daya Tanggap (Responsiveness)}

Yang dimaksud dengan daya tanggap adalah kemampuan pegawai memberikan dalam memberikan pelayanan secara tanggap kepada pelanggan sesuai dengan tingkat penyerapan, pemahaman, terhadap berbagai hal terkait dengan bentuk pelayanan yang tidak diketahuinya, sehingga pelayanan memperoleh respon positif (Parasuraman, 2001).

Kualitas pelayanan daya tanggap tercermin dalam (1) pemberian penjelasan secara bijaksana sehingga pelanggan mampu memahami dan menyetujui bentuk pelayanan yang diberikan, (2) 
menjelaskan secara detail dan transparan terhadap inti persoalan pelayanan yang diberikan kepada pelanggan, (3) mengarahkan bentuk pelayanan kepada pelanggan agar melaksanakan dan mengikuti ketentuan pelayanan yang harus dipenuhi, dan (4) mengarahkan dan membujuk pelanggan agar kooperatif jika menghadapi masalah yang dianggap bertentangan dengan prosedur pelayanan yang berlaku (Margaretha, 2003).

\section{Jaminan (Assurance)}

Yang dimaksud dengan jaminan adalah bentuk kualitas pelayanan yang menumbuhkan keyakinan pada pelanggan bahwa segala bentuk pelayanan yang diberikan itu dilakukan dengan tuntas, cepat, tepat, mudah, dan lancar (Parasuraman, 2001).

Bentuk jaminan kualitas pelayanan tercermin dalam: (1) memberikan kepuasan pelayanan, yaitu memberikan pelayanan yang cepat, tepat mudah, dan lancar, (2) menunjukkan komitmen kerja yang tinggi secara profesional dengan memperhatikan etos kerja dan budaya kerja yang mengaplikasikan visi dan misi organisasi, dan (3) memberikan kepastian pelayanan yang ditunjukkan melalui perilakunya sehingga pelanggan yakin bahwa pelayanan yang diterima itu tuntas (Margaretha. 2003)

\section{Empati (Emphaty)}

Yang dimaksud dengan empati dalam suatu pelayanan adalah memberikan perhatian, keseriusan, simpatik, serta pemahaman terhadap masalah yang dialami pelanggan kepada pelanggan sesuai dengan tingkat pengertian, pemahaman, dan kebutuhannya (Parasuraman, 2001). Dalam memberikan empati, sebaliknya pihak yang dilayani sebaiknya juga memahami keterbatasan kemampuan dari orang yang melayani sehingga terjadi keterpaduan dan kesamaan perasaan antara pihak yang dilayani dan pihak yang melayani. Pelayanan akan berjalan lancar dan berkualitas jika setiap pihak yang berkepentingan dengan pelayanan memiliki rasa empati serta komitmen yang sama dalam urusan pelayanan (Parasuraman, 2001).

Bentuk empati dalam memberikan pelayanan tampak dalam: (1) perhatian terhadap berbagai bentuk pelayanan yang diberikan sehingga pelanggan merasa menjadi orang penting, (2) keseriusan atas pelayanan yang diberikan sehingga pelanggan merasa bahwa pegawai menunjukkan perilaku positif dan konsisten, (3) rasa simpatik atas pelayanan yang diberikan sehingga pelanggan merasa memiliki wibawa, (4) pengertian yang mendalam atas berbagai hal yang diungkapkan sehingga pelanggan nyaman dalam menghadapi bentuk layanan yang diberikan, dan (5) keterlibatannya dalam berbagai pelayanan terkait dengan bentuk kesulitan dalam aktivitas pelayanan sehingga pelanggan merasa tertolong (Margaretha, 2003).

\section{METODE PENELITIAN}

Penelitian dilakukan pada mahasiswa yang terdapat di lima perguruan tinggi di Jakarta barat. Pengambilan sampel dengan Conveniencesampling yang diambil sebanyak 500 mahasiswa dari 5perguruan tinggi.

Instrumen yang digunakan untuk mengukur profil pelayanan jasa di pendidikan tinggi berupa kuesioner. Pernyataan-pernyataan dalam kuesienerdikembangkan mengacu pada 5 dimensi kualitas layanan SERQUAL yang diidentifikasi oleh PZB (1988). Kelima dimensi itu, yaitu: (1) Bukti fisik 
(Tangibles, (2) Keandalan (Reliability,(3) Daya tanggap (Responsiveness), (4) Jaminan (Assurance), dan (5) Empati (Empathy)

Validitas instrumen dilakukan dengan menggunakan validitas isi (untuk mencocokkan penyataanpernyataan angket dengan 5 dimensi SERQUAL). Hal ini dilakukan karena dalam penelitian ingin memeroleh data yang alami (apa adanya) melalui survei. Validasi isi dilakukan berdasarkan kesepatan para ahli. Setelah dilakukan validitas isi oleh pakar, tersebut direvisi kemudian diuji validitas dan reliabilitas .

Data yang dikumpulkan pada penelitian ini berupa data primer. Teknik pengumpulan data yang digunakan berupa kuesioner dengan skala likert.Teknik analisis data adalah analisis statistik deskriptif untuk mengolah hasil penyebaran kuesioner. Semua Analisis dengan perangkat lunak yang digunakan adalah SPSS

\section{HASIL DAN PEMBAHASAN}

\section{Pengembangan Instrumen Layanan Jasa menurut Pakar}

Dari instrumen yang dikembangkan oleh peneliti kemudian divalidasi oleh pakar. Hasil validasi dari pakar merupakan input yang dapat digunakan sebagai dasar untuk merevisi sehingga diperoleh instrumen valid secara isi. Hasil uji validitas butir pernyataan dari dimensi fisik, keandalan,jaminan dan empati tergolong valid, dimana Corrected Item-Total Correlation tiap butir pernyataan yang lebih besar dari pada 0.20. Hasil Reliabilitas dimensi dan variabel kualitas layanan memiliki nilai Alpha Cronbach lebih besar daripada 0,70 sehingga lima dimensi maupun variabel kualitas layanan tergolong reliabel.

\section{Gambaran Kualitas Layanan Jasa Pendidikan Tinggi}

Deskripsi subyek penelitian dikelompokkan mejadi beberapa yaitu: berdasarkan jenis kelamin, universitas,fakultas, usia dan semester. Berdasarkan jenis kelamin, dari 500 responden terdapat 248 orang (49,6 persen) perempuan dan 252 orang (50,4 persen) laki-laki. Berdasarkan universitas dikelompokkan menjadi 5 perguruan tinggi, yaitu U1 sebanyak 167 responden (33,4 persen), U2 sebanyak 90 responden (18 persen), U3 sebanyak 88 responden (17,6 persen), U4 sebanyak 84 responden (16,8 persen), dan U5 sebanyak 71 responden (14,2 persen). Jumlah responden yang terbanyak adalah dari U1, yaitu 167 responden dan yang paling sedikit adalah dari U5, yaitu 71 responden.Untuk fakultas diketahui bahwa mayoritas responden berasal dari Fakultas Ekonomi (324 responden atau 64,8 persen) dan yang minoritas responden berasal dari Fakultas Arsitektur (3 responden atau 0,6 persen). Sebanyak 72 responden (14,4 persen) berasal dari Fakultas Teknik, 58 responden (11,6 persen) dari Fakultas Ilmu Komunikasi, dan 43 responden (8,6 persen) berasal dari Fakultas Hukum. Untuk usia seluruh responden bergerak dari 17 tahun hingga 28 tahun. Responden tersebut merupakan mahasiswa/i semester dua hingga delapan.

Hasil gambaran tiap variable dan dimensi terdapat pada table 2 sampi 6. 
Tabel 2. Statistik Deskriptif Variabel dan Dimensi

\begin{tabular}{|l|l|r|r|r|r|}
\hline & $\mathrm{N}$ & Minimum & Maximum & Mean & Std. Deviation \\
\hline Kualitas Layanan & 500 & 2.39 & 5.00 & 3.5827 & .48156 \\
FISIK & 500 & 2.00 & 5.00 & 3.6655 & .55693 \\
ANDAL & 500 & 2.00 & 5.00 & 3.4664 & .61464 \\
TANGGAP & 500 & 1.80 & 5.00 & 3.5520 & .61336 \\
JAMIN & 500 & 1.00 & 5.00 & 3.5128 & .61452 \\
EMPATI & 500 & 2.10 & 5.00 & 3.6328 & .60090 \\
Valid N (listwise) & 500 & & & & \\
\hline
\end{tabular}

Dari Tabel 2 di atas dapat diketahui bahwa dari semua (lima) dimensi pada variabel kualitas layanan, rata-rata dimensi fisik (tangibles) adalah yang berbesar, yaitu 3,66. Dimesi keandalan memiliki rata-rata $(3,47)$ yang paling kecil. Dari segi penyeberan skor, dimensi fisik memiliki deviasi standar $(0,56)$ yang paling kecil dan dimensi keandalah memiliki deviasi standar $(0,61)$ yang paling besar. Itu berarti bahwa dimensi fisik memiliki akurasi pengukuran yang paling baik. Sebaliknya, dimensi keandalah memiliki akurasi pengukuran yang paling jelek.

Tabel 3. Statistik Deskriptif Butir Dimensi Keandalan

\begin{tabular}{|l|r|r|r|r|r|}
\hline & Andal1 & Andal2 & Andal3 & Andal4 & Andal5 \\
\hline $\mathrm{N} \quad$ Valid & 500 & 500 & 500 & 500 & 500 \\
& 0 & 0 & 0 & 0 & 0 \\
Mean & 3.53 & 3.47 & 3.38 & 3.53 & 3.43 \\
Std. Error of Mean & .039 & .038 & .040 & .038 & .038 \\
Mode & 4 & 4 & 4 & 4 & 3 \\
Std. Deviation & .866 & .852 & .883 & .855 & .845 \\
Range & 4 & 4 & 4 & 5 & 4 \\
Minimum & 1 & 1 & 1 & 1 & 1 \\
Maximum & 5 & 5 & 5 & 6 & 5 \\
\hline
\end{tabular}

Statistik deskriptif butir pernyataan dimensi keandalan disajikan pada Tabel 3. Dari tabel itu dapat diketahui bahwa pernyataan 1 dan 4 memiliki rata-rata $(3,53)$ terbesar. Butir pernyataan 3 memiliki rata-rata $(3,38)$ terkecil. Akurasi pengukuran butir pernyataan 3 adalah yang paling jelek, sebagaimana dapat diketahui dari deviasi standarnya sebesar 0,883. Akurasi pengukuran butir pernyataan 5 adalah yang paling baik, sebagaimana dapat diketahui dari deviasi standarnya sebesar 0,845 . 
Tabel 4 Statistik Deskriptif Butir Dimensi Ketanggapan

\begin{tabular}{|c|c|c|c|c|c|}
\hline & Tanggap1 & Tanggap2 & Tanggap3 & Tanggap4 & Tanggap5 \\
\hline Valid & 500 & 500 & 500 & 500 & 500 \\
\hline Missing & 0 & 0 & 0 & 0 & \\
\hline Mean & 3.49 & 3.64 & 3.52 & 3.49 & 3.62 \\
\hline Std. Error of Mean & .035 & .036 & 036 & .036 & .036 \\
\hline Mode & 4 & 4 & 4 & 3 & 4 \\
\hline Std. Deviation & .779 & .800 & .804 & .794 & .795 \\
\hline Range & 4 & 4 & 4 & 4 & 4 \\
\hline Minimum & 1 & 1 & 1 & 1 & 1 \\
\hline Maximum & 5 & 5 & 5 & 5 & 5 \\
\hline
\end{tabular}

Statistik deskriptif butir pernyataan dimensi ketanggapan disajikan pada Tabel 4. Butir pernyataan 2 memiliki rata-rata yang terbesar, yaitu 3,64. Butir pernyataan 1 dan 4 memiliki rata-rata yang terkecil, yaitu 3,49. Akurasi butir pernyataan 1 adalah yang terbaik, sebagaimana dapat diketahui dari deviasi standarnya $(0,779)$ yang terkecil. Akurasi butir pernyataan 3 adalah yang paling jelek, sebagaimana dapat diketahui dari deviasi standarnya $(0,804)$ yang paling besar.

Statistik deskriptif butir pernyataan dimensi jaminan disajikan pada Tabel 5. Butir pernyataan 1 dan 5 memiliki rata-rata yang terbesar, yaitu 3,54. Butir pernyataan 4 memiliki rata-rata yang terkecil, yaitu 3,43. Akurasi butir pernyataan 3 adalah yang terbaik, sebagaimana dapat diketahui dari deviasi standarnya $(0,809)$ yang terkecil. Akurasi butir pernyataan 5 adalah yang paling jelek, sebagaimana dapat diketahui dari deviasi standarnya $(0,864)$ yang paling besar.

Tabel 5 Statistik Deskriptif Butir Dimensi Jaminan

\begin{tabular}{|l|r|r|r|r|r|}
\hline & Jamin1 & Jamin2 & Jamin3 & Jamin4 & Jamin5 \\
\hline $\mathrm{N} \quad$ Valid & 500 & 500 & 500 & 500 & 500 \\
Mean Missing & 0 & 0 & 0 & 0 & 0 \\
Std. Error of Mean & 3.54 & 3.53 & 3.53 & 3.43 & 3.54 \\
Mode & .038 & .037 & .036 & .038 & .039 \\
Std. Deviation & 4 & 4 & 4 & 3 & 3 \\
Range & .859 & .816 & .809 & .860 & .864 \\
Minimum & 4 & 4 & 4 & 4 & 4 \\
Maximum & 1 & 1 & 1 & 1 & 1 \\
\hline
\end{tabular}


Tabel 6 Statistik Deskriptif Butir Dimensi Empati

\begin{tabular}{|l|r|r|r|r|r|r|r|r|r|r|}
\hline & E1 & E2 & E3 & E4 & E5 & E6 & E7 & E8 & E9 & E10 \\
\hline $\mathrm{N} \quad$ Valid & 500 & 500 & 500 & 500 & 500 & 500 & 500 & 500 & 500 & 500 \\
Mean & 0 & 0 & 0 & 0 & 0 & 0 & 0 & 0 & 0 & 0 \\
Std. Error of Mean & 3.67 & 3.72 & 3.63 & 3.66 & 3.47 & 3.56 & 3.55 & 3.69 & 3.73 & 3.64 \\
Mode & .037 & .037 & .037 & .040 & .043 & .043 & .043 & .038 & .041 & .044 \\
Std. Deviation & 4 & 4 & 4 & 4 & 4 & 4 & 4 & 4 & 4 & 4 \\
Range & .834 & .825 & .825 & .889 & .950 & .970 & .972 & .841 & .917 & .985 \\
Minimum & 4 & 4 & 4 & 4 & 4 & 4 & 4 & 4 & 4 & 4 \\
Maximum & 1 & 1 & 1 & 1 & 1 & 1 & 1 & 1 & 1 & 1 \\
\hline
\end{tabular}

Statistik deskriptif butir dimensi empati disajikan pada Tabel 6. Dari tabel itu dapat diketahui bahwa butir pernyataan 9 memiliki rata-rata $(3,73)$ yang terbesar dan butir pernyataan 5 memiliki rata-rata $(3,47)$ yang terkecil. Dari segi akurasi pengukuran, butir pernyataan 2 dan 3 memiliki adalah yang terbaik, sebagaimana dapat diketahui dari deviasi standarnya, yaitu 0,825. Butir pernyataan 10 memiliki akurasi pengukuran yang terjelek, sebagaimana ditunjukkan dengan deviasi standar yang terbesar, yaitu 0,98

\section{Pemetaan Layanan Kualitas Pelayanan Jasa di Perguruan Tinggi Swasta}

Berdasarkan gambaran hasil secara deskriptif, layanan jasa dapat dipetakan sebagai berikut.

Tabel 7. Rata-rata Dimensi dan Kualitas Layanan (KL) per Universitas

\begin{tabular}{|c|c|c|c|c|c|c|}
\hline UNIVERSITAS & FISIK & ANDAL & TANGGAP & JAMIN & EMPATI & KL \\
\hline U1 & 3.76 & 3.45 & 3.55 & 3.51 & 3.73 & 3.64 \\
\hline U2 & 3.58 & 3.42 & 3.48 & 3.44 & 3.68 & 3.54 \\
\hline U3 & 3.82 & 3.55 & 3.61 & 3.49 & 3.80 & 3.69 \\
\hline U4 & 3.47 & 3.45 & 3.46 & 3.51 & 3.15 & 3.37 \\
\hline U5 & 3.57 & 3.47 & 3.69 & 3.62 & 3.70 & 3.62 \\
\hline TOTAL & 3.66 & 3.47 & 3.55 & 3.51 & 3.63 & 3.62 \\
\hline
\end{tabular}

Berdasarkan Tabel 7 (yang merupakan pengolahan data dari data kuesioner tertutup) di atas tampak bahwa layanan jasa berdasarkan dimensi, di semua universitas berada di atas rata-rata, yaitu 3.47 3.82, dengan dasar bahwa skor penilaian bergerak dari 1 -5 sehingga skor rata-rata yaitu 3 $[(1+2+3+4+5) / 5)]$. Nilai rata-rata terbesar yaitu 3.82 dari Universitas U1 dan nilai rata-rata terkecil, yaitu 3.47 dari Universitas U2. Walaupun layanan jasa di semua universitas menunjukkan di atas rata-rata, selisihnya kurang dari 1 ( dari alternatif pilihan di kuesioner, bahwa penilaian baik/ setuju yaitu 4 dan penilaian sangat baik/setuju yaitu 5). Artinya, pelayanan jasa di perguruan tinggi yang menjadi sampel baru dalam ketegori "cukup".

Selain berdasarkan hasil jawaban-jawaban responden dari kuesioner tertutup, terdapat masukan dari beberapa responden pada kuesioner terbuka. Masukan tersebut menyangkut pada keinginan 
perbaikan layanan dimensi fisik. Bentuk masukan meliputi perlunya perbaikan wifi/wifi lambat ( 30 responden), lokasi kantin yang yang tidak strategis/ jauh dari jangkaun sehingga menghabiskan waktu istirahat (25 responden), perlunya ruang santai/taman yang bisa (28) sekaligus untuk belajar .

\section{Pembahasan}

Instrumen kualitas layanan yang dihasilkan dalam panalitian ini berdasarkan lima dimensi, yaitu fisik (tangibles), reliabilitas (reliability), ketanggapan (responsiveness), jaminan (assurance), dan empati (empathy). Penelitian ini sesuai dengan penelitian yang telah ada (Wee dan Nankervis, 2012; Shah, 2013; Ansary, Jayashree dan Malarvizhi, 2014; Borges, Santos dan Leal, 2014; Chopra, Chawla, dan Sharma, 2014; Green, 2014; Sanchez dan Pazos, 2014; Mukhtar, Anwar, Ahmed dan Baloch, 2015). Hasil itu juga sesuai dengan yang diperoleh Parasuraman, Zeithaml, dan Berry (1991) setelah mereka menyempurnakan penelitian awalnya melalui beberapa kali penelitian.

Berdasarkan hasil analisis layanan jasa berdasarkan dimensi, di semua universitas berada di atas rata-rata, yaitu $3.47-3.82$, dengan dasar bahwa skor penilaian bergerak dari $1-5$ sehingga skor ratarata yaitu $3[(1+2+3+4+5) / 5)]$. Nilai rata-rata terbesar yaitu 3.82 dari Universitas U1 dan nilai ratarata terkecil, yaitu 3.47 dari Universitas U2. Walaupun layanan jasa di semua universitas menunjukkan di atas rata-rata, selisihnya kurang dari 1 ( dari alternatif pilihan di kuesioner, bahwa penilaian baik/ setuju yaitu 4 dan penilaian sangat baik/setuju yaitu 5). Artinya, pelayanan jasa di perguruan tinggi yang menjadi sampel baru dalam ketegori "cukup" sehingga kualitas pelayanan jasa di perguruan tinggi masih perlu ditingkatkan.

Pemetaan gambaran hasil penelitian tentang profil layanan jasa di semua perguruan tinggi sebagai sampel penelitian, yang rata-rata masih menunjukkan kategori cukup, sebenarnya juga dialami oleh perguruan tinggi lain dari penelitian sebelumnya. Hasil penilitian sebelumnya menunjukkan bahwa bahwa kualitas pelayanan di pendidikan tinggi belum dapat memuaskan mahasiswa (Siregar \& Zulaihah, 2010; Bangun, A. Ginting, R, \& Tarigan, U., 2013; Hasibuan Sutrisno, 2017). Berdasarkan beberapa penelitian tentang kualitas jasa yang hasilnya belum memuaskan, peneliti tertarik untuk mengetahui bagaimana profil kualitas pelayanan jasa pendidikan tinggi di area Jakarta Barat.

\section{SIMPULAN DAN SARAN \\ Simpulan}

Validitas dan reliabilitas instrumen yang digunakan teruji secara empiris. Koefisien validitas butir pernyataan yang diperoleh bergerak dari 0,443 sampai dengan 0,631. Koefisien reliabilitas kelima dimensi bergerak dari 0,760 (dimensi keandalan) sampai dengan 0,860 (dimensi empati). Koefisien reliabilitas variabel kualitas layanan sama dengan 0,919.Dapat disimpulkan bahwa instrumen valid dan reliabel sehingga dapat digunakan dalam pengambilan data penelitian.

Semua universitas memiliki nilai rata-rata skor untuk kelima dimensi (fisik, keandalan, ketanggapan, jaminan, dan empati) maupun variabel kualitas layanan di atas nilai skor rata-rata (yaitu 3). Artinya, kualitas layanan jasa di semua perguruan tinggi tergolong dalam kategori "cukup". Dengan demikian, tidak ada satu pun universitas yang memiliki nilai rata-rata skor yang mencapai 4 (tergolong baik yang dijawab "setuju" dalam kuesioner), baik dari segi dimensi maupun variabel kualtias layanan, sehingga kualitas pelayanan jasa masih perlu ditingkatkan. 


\section{Saran}

Mengacu pada rata-rata skor yang dimiliki lima universitas untuk lima dimensi dan variabel kualitas layanan, maka usaha untuk meningkatkan skor itu perlu dilakukan sehingga paling sedikit tiap unversitas memiliki rata-rata skor minimal 4 (baik). Hal itu dapat dilakukan dengan mengidentifikasi skor universitas yang lebih kecil dari 4.

Instumen yang dianalisis didasarkan pada lima universitas yang ada di wilayah DKI Jakarta. Terkait dengan itu, perluasan terhadap universitas lainnya perlu dilakukan sehingga validitas eksternal (generalisasi) instrumen itu menjadi makin baik.

Berdasarkan beberapa masukan mengenai perlunya perbaikan dari dimensi fisik, untuk melakukan pengukuran pelayanan jasa, perlu dipertimbangkan dalam penambahan penyataan pada butir instrumen.

\section{REFERENSI}

Ansary, A., Jayashree, S. and Malarvizhi, C. A. N. (2014). The effect of gender and nationality on service quality in Malaysian. The Journal of Developing Areas, 48(4), 97-118.

Babakus, Emin and Boller, Gregory W. (1992). An empirical assessment of the SERVQUAL scale. Journal of Business Research, 24(3), 253-70.

Bangun, A. Ginting, R, \& Tarigan, U. (2013). Analisis kualitas pelayanan jasa pendidikan dengan menggunakan quality function deployment di jurusan akuntansi xyz. e-Jurnal Teknik Industri FT USU. 3 (1), 47-51

Borges, L. F. M., Santos, C. K. S. and Leal, E. A. (2014). Quality in educational service: expectations versus performance in the accounting undergraduate course. Eeuropean Scientific Journal, 10(1), 100-114.

Brady, M. K. and Cronin, J. J. (2001). Some new thoughts on conceptualizing perceived serviced quality: a hierarchical approach. Journal of Marketing,65(3), 34-49.

Buttle, Francis (1996). SERVQUAL: review, critique, research agenda. EuropeanJournal of Marketing, 30(1), 8-32.

Chopra, R., Chawla, M. and Sharma, T. (2014). Service quality in higher education: a comparative study of management and education institutions. NMIMS Management Review, XXXIV (AprilMay), 59-72.

Cronin, J. Joseph, Jr. and Taylor, Steven A. (1992). Measuring service quality: a reexamination and extension. Journal of Marketing, 56(July), 55-68. and (1994). SERVPERF versus SERVQUAL: reconciling performance-based and perceptions-minus-expectations measurement of service quality. Journal of Marketing, 58(January), 125-131.

Dotchin, John A. and Oakland, John S. (1994). Total quality management in services - Part 3: Distinguishing perceptions of service quality. The International Journal of Quality \& Reliability Management, 11(4), 6-29.

Fiegenbaum, A., V. 1996. Total Quality Control. New York: McGraw-Hill Book.

Firdaus Abdullah (2006). Measuring service quality in higher education: HEdPERF versus SERVPERF. Marketing Intelligence \& Planning, 24(1), 31-47.

Ford, J. W., M. Joseph and B. Joseph (1999). Importance-performance analysis as a strategic tool for service marketers: the case of service quality perceptions of business students in New Zealand and the USA. Journal of Services Marketing, 13(1), 171-186. 
Green, Paul (2014). Measuring service quality in higher education: a South African case study. Journal of International Education Research, 10(2), 131-142.

Gunawan, Imam. (2012). Diunggah $12 \quad$ April 2016 dalam http://masimamgun.blogspot.co.id/2012/11/kualitas-layanan-pendidikan.html.

Hasibuan, F.C dan Sutrisno. (2017). Identifikasi tingkat kualitas pelayanan jasa pendidikan dengan menggunakan servqual di Fakultas Teknik Universitas X. Spektrum Industri, 15 (1), 1 -

Holdford D, Patkar A. (2003). Identification of the Service Quality Dimensions of Pharmaceutical Education. Am J Pharm Educ. 67(4): article 108, 1-11.

Hussey, M. K. (1999). Using the cocept of loss: an alternative SERVQUAL measure. The Service Industries Journal, 19(4), 89-101.

Mahmoud, A. B. and Khalifa, B. (2015). A conformatory factor analysis for SERVPERF instrument based on a sample of students from Syrian universities. Education + Training, 57(3), 343-359.

Margaretha. (2003). Kualitas pelayanan: teori dan aplikasi. Jakarta: Mandar Maju.

Mukhtar, U., Anwar, S., Ahmed, U. and Baloch, M. A. (2015). Factors effecting the service quality of public and private sector universities comparatively: an empirical investigation. Journal of Arts, Science \& Commerce, VI(3(1)), 132-144.

Nasseef, M. A. (2014). Measuring the quality of educational service provided by business administration department using the SERVQUAL instrument at King Abdul-Aziz University. Journal of Business Studies Quarterly, 5(4), 147-172.

Parasuraman, A., Valerie A. Zeithaml, and Leonard L. Berry (1985). A conceptual model of service quality and its implications for future research. Journal of Marketing, 49(4), 41-50 , and __ (1988). SERVQUAL: A multiple-item scale for measuring perceptions of service quality. Journal of Retailing, 64(1), 12-40.

, Leonard L. Berry, and Valerie A. Zeithaml (1991). Refinement and reassessment of the SERVQUAL scale. Journal of Retailing, 67(4), 420-50.

, Leonard L. Berry, and Valerie A. Zeithaml (1991). Refinement and reassessment of the SERVQUAL scale. Journal of Retailing, 67(4), 420-50.

-. (2001). Delivering quality service. (Diterjemahkan oleh Sutanto). New York: The Free Pres.

Peter, J., G. Churchill, and T. Brown (1993). Caution in the use of difference scores in consumer research. Journal of Consumer Research, 19(4), 655-62.

Sánchez, O. R. and Pazos, M. R. (2014). Percepción de la calidad del servicio educativo doctoral. Global Conference on Business and Finance Proceedings, 9(1), 1672-1679.

Shah, F. T. (2013). Service quality and customer satisfaction in higher education in Pakistan. Journal of Quality and Technology Management, IX (II), 73-89.

Siregar, A.H. dan Zulaihah, L. (2010). Pengukuran kualitas pelayanan dengan metode student satisfation inventory di UPN Veteran Jakarta. Bina Teknika, 6 (1), 98 - 116.

Susanti, Evi. (2015). The Impact of Internal and External Service Quality. Mediterranean Journal of Social Sciences, VI (5), 77-83.

Sunyoto, Hamingpraja, 2004. Jaminan Kualitas Pelayanan Konsumen. Penerbit Liberty, Yogyakarta.

Wee, M.O. and Nankervis, A. (2012). Service quality in higher education: students' perceptions in Australian and Malaysia. Review of Integrative Business \& Economic Research, I (1), 275 291 